\title{
Klasifikace kvality povrchových vod
}

\section{TOMÁŠ MIČANÍK, EDUARD HANSLÍK, DENISA NĚMEJCOVÁ, DANA BAUDIŠOVÁ}

Klíčová slova: kvalita vody - povrchová voda - klasifikace vody

\section{SOUHRN}

Článek představuje novelizovanou normu ČSN 757221 Kvalita vod - Klasifikace kvality povrchových vod [1], která nahrazuje předchozí 19 let platnou normu [2]. Předmětem novely bylo zohlednit požadavky na současnou úroveň ochrany povrchových vod, a to jak z hlediska ukazatelů znečištění, tak i úrovně prípustného znečištění. Revizí prošel jak rozsah ukazatelů, tak mezní hodnoty tříd kvality. Rozšíření doznal i text normy, a to především v prílohové části: kromě způsobu výpočtu charakteristické hodnoty, který zůstává nezměněn, přibyly další nezbytné pomocné výpočty. Nově je zařazena informativní príloha se stručnou charakterizací jednotlivých ukazatelů kvality vody nebo jejich skupin pro snadnější orientaci především zástupců samosprávných celků na úrovni obcí i široké veřejnosti. Norma nově umožňuje orientační určení kvality vody při nižších četnostech, než je požadováno pro klasifikaci.

\section{ÚVOD}

Kvalita vody je pravidelně klasifikována a vyhodnocována od 60. let 20. století. Klasifikací se pritom rozumí výpočet charakteristické hodnoty (u většiny ukazatelů ze souboru 11 až 24 měření je hodnota nepřesahovaná v 90 \%), její porovnání se soustavou mezních hodnot tříd kvality vody a zařazení ukazatele do jedné z pěti tříd kvality podle znečištění vody. První norma, která se zabývala touto problematikou, byla ČSN 830602 z 23. 6. 1965. Norma obsahovala celkem 25 ukazatelů (ukazatele kyslíkového režimu, ukazatele základního chemického složení, zvláštní ukazatele a ukazatele mikrobiálního znečištění). Norma pro klasifikaci kvality povrchových vod byla pravidelně revidována a $\vee$ souvislosti s výskytem nových znečištujících látek v životním prostředí byly do normy doplňovány další ukazatele kvality vody. V tomto článku je představena revize předchozí normy ČSN 757221 z řína 1998. Obsahuje celkem 65 ukazatelů sdružených $v$ pěti skupinách (obecné, fyzikální a chemické ukazatele, organické látky, kovy a metaloidy, mikrobiologické a biologické ukazatele, radiologické ukazatele).

\section{METODIKA}

Za dobu platnosti normy od roku 1998 do současnosti došlo celkem pětkrát ke změně nařízení vlády, upravující hodnoty prípustného znečištění povrchových vod.' Během té doby byly limitní hodnoty znečištění v souladu se zvyšující se úrovní poznání negativních účinků na vodní prostředí v těchto nařizeních několikrát změněny. $\vee$ prvním kroku prací na novele ČSN bylo třeba ověřit, zda mezní hodnoty tříd kvality v normě odpovídaji současným požadavkům ochrany vodního prostředí, či nikoli. Vycházelo se přitom z předpokladu, že III. třída kvality

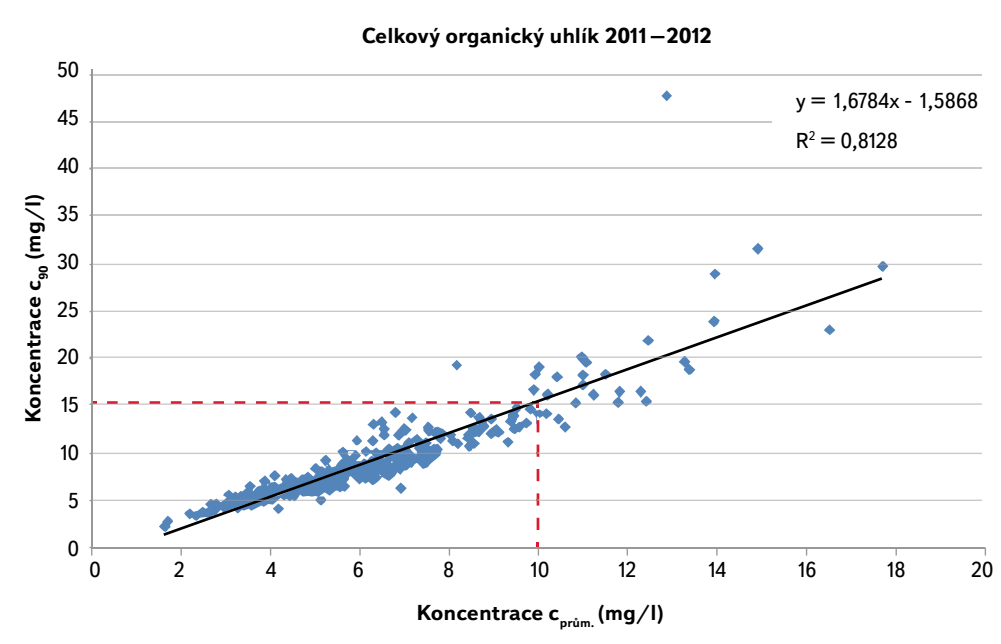

Obr. 1. Závislost průměrné koncentrace TOC na vypočtené hodnotě $C_{90}$ v profilech sledování jakosti povrchových vod ve dvouletí 2011-2012; červená přerušovaná čára naznačuje způsob odvození III. třídy kvality z NEK-RP

Fig. 1. Concentration dependence of $C_{\text {avg. }}$ to concentration $C_{90}$ of TOC in the surface water monitoring sites in two-year period 2011-2012; the red dash line shows method to derive III. class of the water quality from AA-EQS

normy ČSN 75 7221, charakterizující znečištěnou vodu, by měla být srovnatelná s hodnotou přípustného znečištění povrchových vod, resp. s normou environmentální kvality nařizení vlády č. 401/2015 Sb. [3]. Tento předpoklad byl patrně uplatněn i v době prípravy normy z roku 1998. Pokud se provede porovnání hodnot prípustného znečištění povrchových vod určených nařízením vlády č. 171/1992 Sb. [4] s III. trídou kvality původní normy, tak u řady ukazatelů jsou patrné shodné limitní hodnoty (užitím shodné charakteristické hodnoty koncentrace $C_{90}$ v obou predpisech bylo možné provést prímé srovnání).

Hodnoty prípustného znečištění a norem environmentální kvality (NEK) uvedené v príloze č. 3 k nařízení vlády č. 401/2015 Sb. byly přepočítány z průměru, popř. z nejvyšší prípustné koncentrace, na charakteristickou hodnotu $C_{90}$ (koncentrace nepřesahovaná v 90 \%). Základem pro přepočet se staly výsledky monitorování jakosti povrchových vod na území celé ČR za období 2006 až 2012. Data byla pro potřeby výpočtu $C_{90}$ agregována do dvouletí 2006-2007, 2007-2008 a 2011-2012. Následně byly vypočteny koncentrační charakteristiky: průměr, minimum, maximum, medián a $C_{90}$ pro každý ukazatel znečištění. Výpočet $C_{90}$ byl proveden shodně podle odst. 4.6 a normativní prílohy A ČSN 757221 . Hodnoty pod mezí stanovitelnosti (<MS) byly v souladu s používanými metodickými postupy upraveny na $1 \frac{1}{2}$ MS nebo na 0 u sdružených ukazatelů. $Z$ vynesené závislosti průměrné koncentrace v profilech sledování $C_{\text {prüm. }}$ na $C_{90}$ byla dosazením NEK do získané rovnice vypočtena hodnota $C_{90^{\prime}}$ která se 
stala základem pro určení III. třídy kvality (obr. 1). Porovnáním závislostí za testovaná dvouletí bylo také ověřeno, že se konverzní faktor $C_{\text {prưm. }} / C_{90}$ mezi testovanými dvouletími u naprosté většiny ukazatelů přiliš nemění (tabulka 1). Výjimkou jsou ukazatele, které vykazují vyšší rozptyl koncentrací nebo převládají výsledky pod mezí stanovitelnosti s občasnými pozitivními nálezy (např. u pesticidů).

Pokud bylo potřeba III. třídu kvality revidovat, což bylo u většiny ukazatelů, byly následně upraveny i ostatní mezní třídy tak, aby co nejlépe vystihovaly jednotlivé třídy kvality I. až V. Bylo dbáno na to, aby navržená V. třída kvality - velmi silně znečištěná voda - nebyla vyšší než nejvyšší přípustná koncentrace (NPK) daná přilohou č. 3 k nařízení vlády č. 401/2015 Sb. (v případě ukazatelů, pro které je NEK-NPK určena).

Revizi byly podrobeny i jednotlivé ukazatele. Ty z nich, které již na základě výsledků dlouhodobého pravidelného monitoringu prováděného v ČR nepredstavují riziko pro vodní prostředí nebo pro další užívání vod, byly z tabulky 1 normy ČSN 757221 vyjmuty: vápník, hořčík, chlorované uhlovodíky 1,2-dichlorethan, trichlormethan, tetrachlormethan, chlorbenzen, lindan a PCB. Naopak vlivem postupně se rozšiřujícího rozsahu monitorovaných ukazatelů $v$ povrchových vodách byly přidány ukazatele, jejichž míra výskytu ve vodách je významná (koncentrace $C_{90}$ zasahovala do odvozené III. a vyšší třídy kvality). K rozšíření došlo predevším ve skupinách "Organické látky“ a "Kovy a metaloidy". Mezní hodnoty tříd kvality jsou tak určeny pro celkem 65 ukazatelů (v původní normě pro 46 ukazatelů).

\section{KLASIFIKACE}

Princip klasifikace zůstává shodný s předchozí verzí normy. Tekoucí povrchové vody se podle kvality vody zařazují do pěti tříd kvality:

I. neznečištěná voda,

II. mírně znečištěná voda,

III. znečištěná voda,

IV. silně znečištěná voda,

V. velmi silně znečištěná voda.

Rovněž princip výpočtu charakteristické hodnoty $C_{90}$ zůstává nezměněn. Charakteristická hodnota ukazatele kvality vody (odstavec 4.4) je hodnota s pravděpodobností nepřekročení $90 \%$, u rozpuštěného kyslíku s pravděpodobností překročení $90 \%$. U ukazatele saprobní index makrozoobentosu se jako charakteristická hodnota použije aritmetický průměr $v$ hodnoceném období. Jako charakteristická hodnota ukazatele chlorofyl-a se použije maximální hodnota z daného počtu naměřených hodnot za vegetační období (březen až řijen). Kvalita vody se klasifikuje na základě výsledků monitoringu z delšího hodnoceného období, doporučuje se dvouletí, maximálně však pětiletí.

Rozsah ukazatelů spadajících do tzv. základní klasifikace zůstal zachován: $\mathrm{BSK}_{5^{\prime}} \mathrm{CHSK}_{\mathrm{C}^{\prime}} \mathrm{N}-\mathrm{NO}_{3} ; \mathrm{N}-\mathrm{NH}_{4}{ }^{+}, \mathrm{P}_{\text {celk }}$ a saprobní index makrozoobentosu. Kromě základní klasifikace je možné pro doplňkovou (účelovou) klasifikaci libovolně (na základě daného účelu hodnocení) zvolit vlastní rozsah ukazatelů. Je ale nutné dodržet podmínku, aby výsledky stanovení všech ukazatelů obsažených ve skupinách byly klasifikovány na všech společně hodnocených profilech. Výsledná třída se určí podle nejnepříznivějšího zatřídění zjištěného u jednotlivých vybraných ukazatelů. Norma je rozšířena o novou informativní př́lohu B, která stručně charakterizuje jednotlivé ukazatele kvality vody nebo jejich skupin.
Tabulka 1. Poměr koncentračnich charakteristik $C_{9 d} / C_{\text {prüm. }}$ v testovaných dvouletích pro vybranéukazatele

Table 1. Relationship between $C_{9 d} C_{\text {avg. }}$ concentration in two-year periods for selected parameters

\section{Ukazatel}

Poměr $\mathrm{C}_{90} / \mathrm{C}_{\text {prům. }}$ za dvouletí

\begin{tabular}{lccc} 
& 2006-2007 & 2007-2008 & 2011-2012 \\
\hline rozpuštěné látky sušené & 1,31 & 1,26 & 1,21 \\
\hline nerozpuštěné látky sušené & 1,81 & 2,10 & 2,06 \\
\hline rozpuštěný kyslík & 0,68 & 0,68 & 0,67 \\
\hline
\end{tabular}

\begin{tabular}{llll}
\hline $\begin{array}{l}\text { biochemická spotřeba kys- } \\
\text { líku, pětidenní }\end{array}$ & 1,69 & 1,65 & 1,63 \\
\hline
\end{tabular}

chemická spotřeba kyslíku

\begin{tabular}{lccc}
$\begin{array}{l}\text { Chemická spotřeba kyslíku } \\
\text { dichromanem }\end{array}$ & 1,45 & 1,38 & 1,41 \\
\hline amoniakální dusík & 2,30 & 2,17 & 2,26 \\
\hline dusičnanový dusík & 1,48 & 1,53 & 1,34 \\
\hline celkový dusík & 1,47 & 1,46 & 1,49 \\
\hline celkový fosfor & 1,60 & 1,73 & 1,73 \\
\hline $\begin{array}{l}\text { adsorbovatelné organicky } \\
\text { vázané halogeny }\end{array}$ & 1,62 & 1,58 & 1,62 \\
\hline
\end{tabular}

\begin{tabular}{lccc}
\hline $\begin{array}{l}\text { 1,1,2,2-tetrachlorethen } \\
\text { (perchlorethylen) }\end{array}$ & 2,76 & 1,50 & 1,38 \\
\hline hexazinon & 1,56 & 1,67 & 1,43 \\
\hline chlorotoluron & - & 2,38 & 2,03 \\
\hline
\end{tabular}

\begin{tabular}{lccc}
\hline $\begin{array}{l}\text { kyselina } \\
\text { ethylendiamintetraoctová }\end{array}$ & 1,97 & 1,96 & 1,74 \\
\hline $\begin{array}{l}\text { polycyklické aromatické } \\
\text { uhlovodíky }\end{array}$ & 2,64 & 4,46 & 2,38 \\
\hline arsen & 1,75 & 1,72 & 1,71 \\
\hline měd' (celkový vzorek) & 1,70 & 1,80 & 1,90 \\
\hline olovo (celkový vzorek) & 1,95 & 2,02 & - \\
\hline olovo (rozpuštěná fáze) & - & - & 2,67 \\
\hline rtứ (celkový vzorek) & 2,00 & 2,29 & - \\
\hline zinek & 1,85 & 1,75 & 1,70
\end{tabular}

Nově je umožněno tzv. orientační určení kvality vody ze souboru méně než 11 naměřených hodnot (méně než 6 hodnot v prípadě koncentrace chlorofylu-a, popř. jedné hodnoty saprobního indexu podle makrozoobentosu). V tom prípadě se použije maximální naměřená hodnota, která se porovná s mezní hodnotou př́slušné třídy kvality. 

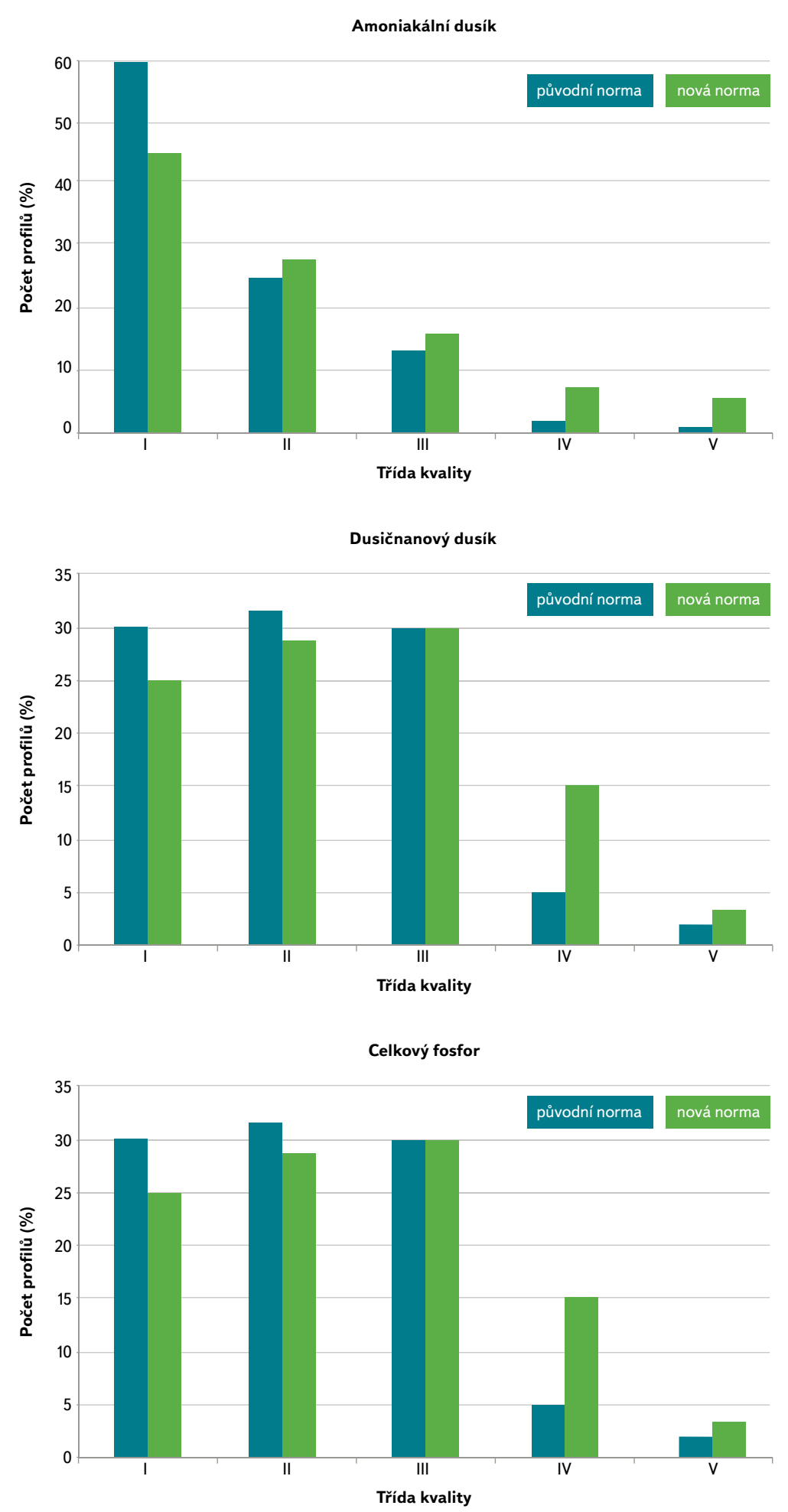

Obr. 2. Srovnání zatȟídění profilu sledování jakosti povrchových vod podle původní a nové normy ČSN 75 7221, $\mathrm{n}=932$ profilů $\left(\mathrm{N}-\mathrm{NH}_{4}^{+}{ }^{+}\right), \mathrm{n}=913$ profilů $\left(\mathrm{N}-\mathrm{NO}_{3}^{-}\right)$a $\mathrm{n}=919$ profilů $\left(P_{\text {celk }}\right) z$ dat monitoringu za období 2011-2012

Fig. 2. A comparison of the surface water monitoring site classification according to the original and new ČSN $757221, n=932$ sites $\left({\mathrm{N}-N H_{4}}^{+}\right), \mathrm{n}=913$ sites $\left(\mathrm{N}^{-\mathrm{NO}_{3}}{ }^{-}\right)$and $\mathrm{n}=919$ sites $\left(P_{\text {total }}\right)$ from monitoring period 2011-2012

\section{OBECNÉ, FYZIKÁLNÍ A CHEMICKÉ UKAZATELE}

Ukazatele uvedené v tabulce 1 normy Mezní hodnoty tříd kvality jsou rozděleny do několika skupin. V rámci skupiny "Obecné, fyzikální a chemické ukazatele“ došlo především ke zprísnění mezních hodnot charakterizujících úživnost vod, a to především v prípadě amoniakálního dusíku. Nově byly zařazeny ukazatele dusitanový dusík a celkový dusík. Stávající a nově navržené mezní hodnoty tříd kvality pro vybrané ukazatele jsou uvedeny v tabulce 2. Jak se změní rozsah klasifikovaných profilů v jednotlivých tř́íách podle stávající a nové normy, znázorňuje obr. 2. Amoniakální dusík ve vodním prostředí vlivem biochemických preměn za prítomnosti kyslíku oxiduje na dusitany a dále na dusičnany. Dusitany jsou ve zvýšené miře obsaženy i v odpadních vodách z vybraných strojírenských procesů (obrábění kovů) nebo se mohou vyskytovat ve vodách s intenzivním chovem ryb [5]. V celkovém dusíku je zahrnuta i složka organického dusíku, která není zanedbatelná [6]. Celkový dusík byl do normy zařazen také z toho důvodu, že je povinným ukazatelem kontroly jakosti odpadních vod podle nařízení vlády č. 401/2015 Sb. pro kategorie ČOV nad 10 tis. ekvivalentních obyvatel. Nově byly odvozeny mezní hodnoty tříd také pro fluoridy a kyanidy. Je potěšující, že u většiny základních ukazatelů (elektrolytická konduktivita, rozpuštěné látky, biochemické i chemické spotřeby kyslíku, celkového organického uhlíku, chloridů a síranů) nedošlo ke změnám mezních hodnot. Tím zůstává zachována kontinuita hodnocení kvality povrchových vod tekoucích z predchozích let.

\section{ORGANICKÉ LÁTKY}

Největších změn v nové normě doznala skupina ukazatelů "Organické látky“. Z původního výčtu zůstaly 1,1,2-trichlorethen, 1,1,2,2-tetrachlorethen, dichlorbenzeny, adsorbovatelné organické halogeny (AOX) a polyaromatické uhlovodíky (PAU). Mezní hodnoty tříd kvality pro dichlorbenzeny a PAU byly výrazně zpřísněny, naopak u AOX změkčeny. Dưvodem tohoto změkčení je potvrzený významný podíl AOX prírodního původu v lesních půdách a povrchové vodě vlivem prírodní chlorace organické hmoty [7]. Nově bylo v rámci této skupiny do normy zařazeno 16 ukazatelů, převážně pesticidů, jejichž zastoupení v povrchových vodách je v takové míre, že byly, i když ojediněle, klasifikovány III. nebo i vyšší třídou kvality. Protože mnohé pesticidy v životním prostředí metabolizují v takové míře, že jejich metabolity ve vodním prostředí převládají, v př́padech, kdy je to stanoveno, se k původní účinné látce zahrnují. Způsob přepočtu metabolitů na účinnou složku je uveden v části A4 normativní př́lohy A.

K nově zařazeným ukazatelům náleží dále bisfenol A, který je široce používán a je potvrzen jako endokrinní disruptor [8]. Téměř jedna třetina z celkového počtu monitorovaných profilů $(n=94)$ spadá do III. tríidy kvality. Skupinu široce používaných změkčovadel plastických hmot v nové normě ČSN 757221 reprezentuje bis(2-ethylhexyl)ftalát, známý též pod zkratkou DEHP. Tato látka náleží k prioritním rizikovým látkám pro vodní prostředí a je také na seznamu látek vzbuzujících mimořádné obavy podle legislativy REACH (toxická pro reprodukci) [9]. Více než $1 \frac{1}{3}$ z celkového počtu profilů, ve kterých je monitorován $(n=67)$, spadá do III. třídy kvality a ojediněle i do IV. třídy kvality. Poslední látku, kterou je potřeba v této skupině zmínit, je kyselina ethylendiamintetraoctová (EDTA). Pro své komplexotvorné vlastnosti se používá pro změkčování vody, je součástí pracích prostředků a prípravků v průmyslu i v domácnostech. Ve vodním prostředí je limitována kvůli špatné biologické odbouratelnosti. $V$ hodnoceném období 2011-2012 se $90 \%$ profilů z celkového počtu monitorovaných s dostatečnou četností vzorkování ( $n=91$ ) nacházelo ve II. trídě kvality, jen ojediněle ve III. trídě kvality. Vybrané údaje jsou uvedeny v tabulce 3 a na obr. 3. 
Tabulka 2. Mezni hodnoty tříd kvality - živiny (pưvodní hodnoty černě, nové hodnoty červeně)

Table 2. Threshold limit values of the water quality classes - trophic parameters (original values - black, new values - red)

\begin{tabular}{|c|c|c|c|c|c|c|c|}
\hline \multirow{2}{*}{ Ukazatel } & \multirow{2}{*}{$\begin{array}{l}\text { Zkratka, } \\
\text { značka }\end{array}$} & \multirow{2}{*}{$\begin{array}{l}\text { Měrná } \\
\text { jednotka }\end{array}$} & \multicolumn{5}{|c|}{ Třída kvality } \\
\hline & & & I & II & III & IV & $\mathbf{v}$ \\
\hline amoniakální dusík & $\mathrm{N}-\mathrm{NH}_{4}{ }^{+}$ & mg/l & $\begin{array}{l}<0,3 \\
<0,2\end{array}$ & $\begin{array}{l}<0,7 \\
<0,4\end{array}$ & $\begin{array}{l}<2 \\
<0,8\end{array}$ & $\begin{array}{l}<4 \\
<1,6\end{array}$ & $\begin{array}{l}\geq 4 \\
\geq 1,6\end{array}$ \\
\hline dusitanový dusík & $\mathrm{N}-\mathrm{NO}_{2}^{-}$ & $\mathrm{mg} / \mathrm{l}$ & $<0,05$ & $<0,15$ & $<0,25$ & $<0,4$ & $\geq 0,4$ \\
\hline dusičnanový dusík & $\mathrm{N}-\mathrm{NO}_{3}^{-}$ & $\mathrm{mg} / \mathrm{l}$ & $\begin{array}{l}<3 \\
<2,5\end{array}$ & $\begin{array}{l}<6 \\
<5 \\
\end{array}$ & $\begin{array}{l}<10 \\
<8\end{array}$ & $\begin{array}{l}<13 \\
<12 \\
\end{array}$ & $\begin{array}{l}\geq 13 \\
\geq 12\end{array}$ \\
\hline celkový dusík & $\mathrm{N}_{\text {celk. }}$ & $\mathrm{mg} / \mathrm{l}$ & $<3$ & $<6$ & $<10$ & $<14$ & $\geq 14$ \\
\hline celkový fosfor & $P_{\text {celk. }}$ & $\mathrm{mg} / \mathrm{l}$ & $<0,05$ & $<0,15$ & $\begin{array}{l}<0,4 \\
<0,3\end{array}$ & $\begin{array}{l}<1 \\
<0,6\end{array}$ & $\begin{array}{l}\geq 1 \\
\geq 0,6\end{array}$ \\
\hline
\end{tabular}

\section{KOVY A METALOIDY}

Poslední velkou skupinou chemických ukazatelů jsou „Kovy a metaloidy“. V této skupině byly pưvodně mezní hodnoty tříd kvality specifikovány pro 10 kovů, pro sedm z nich zůstávají v nové normě mezní hodnoty nezměněny. Ke zpřísnění tříd kvality došlo v prípadě chromu, mědi a niklu (tabulka 4). Nově jsou v normě stanoveny třídy kvality pro osm dalších kovů (Ba, Be, B, Al, Co, Se, U, V). Z vyhodnocení výsledkư monitoringu jakosti povrchových vod za období 2001-2012 vyplývá, že v případě kovů (celkový, tj. nefiltrovaný vzorek) dochází k dosahování III. a vyšší třídy kvality jen sporadicky s výjimkou niklu, železa a manganu, u kterých $30 \%, 23 \%$ a $12 \%$ profilů bylo klasifikováno III. třídou.

Tabulka 3. Mezni hodnoty tříd kvality - vybrané organické látky (pưvodní hodnoty černě a nové hodnoty červeně)

Table 3. Threshold limit values of the water quality classes - selected organic compouds (original values - black, new values - red)

\begin{tabular}{|c|c|c|c|c|c|c|c|}
\hline \multirow{2}{*}{ Ukazatel } & \multirow{2}{*}{ Zkratka, č. CAS } & \multirow{2}{*}{ Měrná jednotka } & \multicolumn{5}{|c|}{ Třída kvality } \\
\hline & & & I & II & III & IV & $\mathbf{V}$ \\
\hline 1,1,2-trichlorethen & 79-01-6 & $\mu g / l$ & $<0,2$ & $<1$ & $<2$ & $<3$ & $\geq 3$ \\
\hline 1,1,2,2-tetrachlorethen & $127-18-4$ & $\mu g / l$ & $<0,2$ & $<1$ & $<3$ & $<10$ & $\geq 10$ \\
\hline $\begin{array}{l}\text { adsorbovatelné organické } \\
\text { halogeny }\end{array}$ & AOX & $\mu g / l$ & $\begin{array}{l}<10 \\
<20\end{array}$ & $\begin{array}{l}<20 \\
<40\end{array}$ & $\begin{array}{l}<30 \\
<60\end{array}$ & $\begin{array}{l}<40 \\
<80\end{array}$ & $\begin{array}{l}\geq 40 \\
\geq 80\end{array}$ \\
\hline bisfenol A & 80-05-7 & $\mu g / l$ & $<0,05$ & $<0,15$ & $<0,6$ & $<1,2$ & $\geq 1,2$ \\
\hline bis(2-ethylhexyl)ftalát & DEHP & $\mu g / l$ & $<0,5$ & $<1,1$ & $<2,2$ & $<4$ & $\geq 4$ \\
\hline dichlorbenzeny & DCB & $\mu g / l$ & $\begin{array}{l}<0,2 \\
<0,1\end{array}$ & $\begin{array}{l}<1 \\
<0,2\end{array}$ & $\begin{array}{l}<2 \\
<0,3\end{array}$ & $\begin{array}{l}<3 \\
<0,5\end{array}$ & $\begin{array}{l}\geq 3 \\
\geq 0,5\end{array}$ \\
\hline $\begin{array}{l}\text { kyselina } \\
\text { ethylendiamintetraoctová }\end{array}$ & EDTA & $\mu g / l$ & $<1$ & $<20$ & $<60$ & $<100$ & $\geq 100$ \\
\hline $\begin{array}{l}\text { metolachlor a jeho } \\
\text { metabolity }\end{array}$ & $51218-45-2$ & $\mu g / l$ & $<0,05$ & $<0,2$ & $<0,4$ & $<0,8$ & $\geq 0,8$ \\
\hline metazachlor & $67129-08-2$ & $\mu g / l$ & $<0,05$ & $<0,4$ & $<1,2$ & $<2,4$ & $\geq 2,4$ \\
\hline $\begin{array}{l}\text { polycyklické aromatické } \\
\text { uhlovodíky 1) }\end{array}$ & PAU & $\mu g / l$ & $<0,01$ & $\begin{array}{l}<0,1 \\
<0,03\end{array}$ & $\begin{array}{l}>0,5 \\
<0,1\end{array}$ & $\begin{array}{l}<3 \\
<0,4\end{array}$ & $\begin{array}{l}\geq 3 \\
\geq 0,4\end{array}$ \\
\hline
\end{tabular}



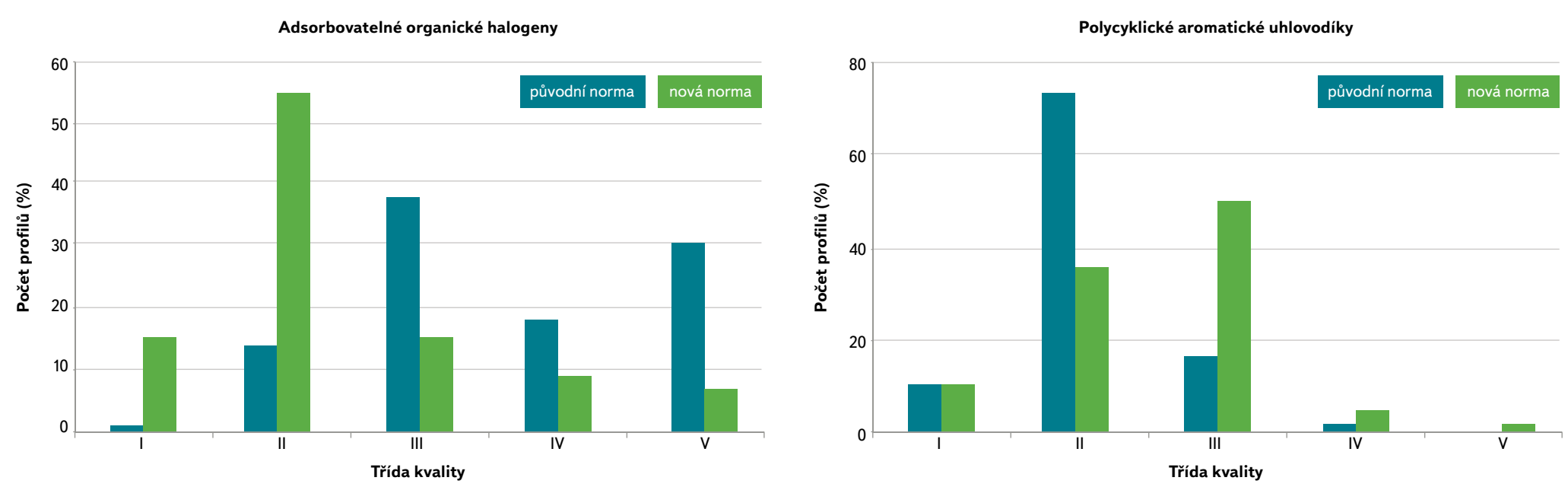

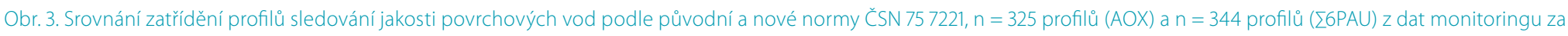
období 2011-2012

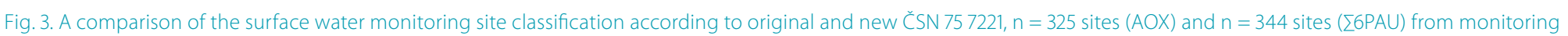
period 2011-2012

Pro vodní organismy je snáze dostupná a tedy i více riziková rozpuštěná forma sloučenin kovů oproti celkové formě [10]. Proto jsou v posledních letech normy environmentální kvality určeny pro rozpuštěnou fázi (filtrovaný vzorek filtrem o velikosti pórů 0,45 mm); na úrovni členských států EU v prípadě kadmia, niklu, olova a rtuti. Třídy kvality byly tedy pro tyto kovy a měd' odvozeny i pro rozpuštěnou formu. Mezní hodnoty $v$ průměru zohledňují poměr mezi celkovým a rozpuštěným obsahem kovu v povrchových vodách ČR. V tabulce 4 jsou mezní hodnoty pro rozpuštěné kadmium uvedeny pouze pro nejčastěji se vyskytující 5. trídu tvrdosti vody, nicméně v normě jsou odvozeny pro všechny třídy tvrdosti vody. Způsob výpočtu tvrdosti vody vyjádřené jako $\mathrm{CaCO}_{3}$ je uveden v části A.2 normativní prílohy A. Na obr. 4 můžete vidět výsledky klasifikace rozpuštěného kadmia v profilech sledování jakosti povrchových vod za období 2011-2012 (žádný profil nespadal do 2. třídy tvrdosti vody, do 1. třídy pak pouze 9 profilů ze 189).

Tabulka 4. Mezní hodnoty tríd kvality - vybrané kovy (původní hodnoty černě a nové hodnoty červeně)

Table 4. Threshold limit values of the water quality classes - selected metals (original values - black, new values - red)

\begin{tabular}{|c|c|c|c|c|c|c|c|}
\hline \multirow{2}{*}{ Ukazatel } & \multirow{2}{*}{ Značka } & \multirow{2}{*}{$\begin{array}{l}\text { Měrná } \\
\text { jednotka }\end{array}$} & \multicolumn{5}{|c|}{ Třída kvality } \\
\hline & & & $\mathbf{I}$ & II & III & IV & $\mathbf{V}$ \\
\hline chrom & $\mathrm{Cr}$ & $\mu g / l$ & $<5$ & $\begin{array}{l}<20 \\
<15\end{array}$ & $\begin{array}{l}<50 \\
<35\end{array}$ & $\begin{array}{l}<100 \\
<70\end{array}$ & $\begin{array}{l}\geq 100 \\
\geq 70\end{array}$ \\
\hline kadmium (celkový vzorek) & $\mathrm{Cd}_{\text {celk. }}$ & $\mu g / l$ & $<0,1$ & $<0,5$ & $<1$ & $<2$ & $\geq 2$ \\
\hline kadmium (rozp. fáze) 5. tř. tvrdosti vody & $\mathrm{Cd}_{\text {rozp. }}$ & $\mu g / l$ & $<0,2$ & $<0,3$ & $<0,45$ & $<1,3$ & $\geq 1,3$ \\
\hline měd' (celkový vzorek) & $\mathrm{Cu}$ celk. & $\mu g / l$ & $<5$ & $\begin{array}{l}<20 \\
<15\end{array}$ & $\begin{array}{l}<50 \\
<30\end{array}$ & $\begin{array}{l}<100 \\
<60\end{array}$ & $\begin{array}{l}\geq 100 \\
\geq 60\end{array}$ \\
\hline měd’ (rozp. fáze) & $\mathrm{Cu}_{\text {rozp. }}$ & $\mu g / l$ & $<3$ & $<8$ & $<16$ & $<32$ & $\geq 32$ \\
\hline nikl (celkový vzorek) & $\mathrm{Ni}_{\text {celk. }}$ & $\mu g / l$ & $\begin{array}{l}<5 \\
<3\end{array}$ & $\begin{array}{l}<20 \\
<6\end{array}$ & $\begin{array}{l}<50 \\
<12\end{array}$ & $\begin{array}{l}<100 \\
<40\end{array}$ & $\begin{array}{l}\geq 100 \\
\geq 40\end{array}$ \\
\hline nikl (rozp. fáze) & $\mathrm{Ni}_{\text {rozp. }}$ & $\mu g / l$ & $<2,5$ & $<5$ & $<10$ & $<30$ & $\geq 30$ \\
\hline olovo (celkový vzorek) & $\mathrm{Pb}_{\text {celk. }}$ & $\mu g / l$ & $<3$ & $<8$ & $<15$ & $<30$ & $\geq 30$ \\
\hline olovo (rozp. fáze) & $\mathrm{Pb}_{\text {rozp. }}$ & $\mu g / l$ & $<0,8$ & $<1,6$ & $<3,2$ & $<8$ & $\geq 8$ \\
\hline rtut' (celkový vzorek) & $\mathrm{Hg}_{\text {celk. }}$ & $\mu g / l$ & $<0,05$ & $\begin{array}{l}<0,1 \\
<0,06\end{array}$ & $\begin{array}{l}<0,5 \\
<0,08\end{array}$ & $\begin{array}{l}<1 \\
<0,1\end{array}$ & $\begin{array}{l}\geq 1 \\
\geq 0,1\end{array}$ \\
\hline rtut' (rozp. fáze) & $\mathrm{Hg}_{\text {rozp. }}$ & $\mu g / l$ & $<0,04$ & $<0,05$ & $<0,06$ & $<0,07$ & $\geq 0,07$ \\
\hline
\end{tabular}




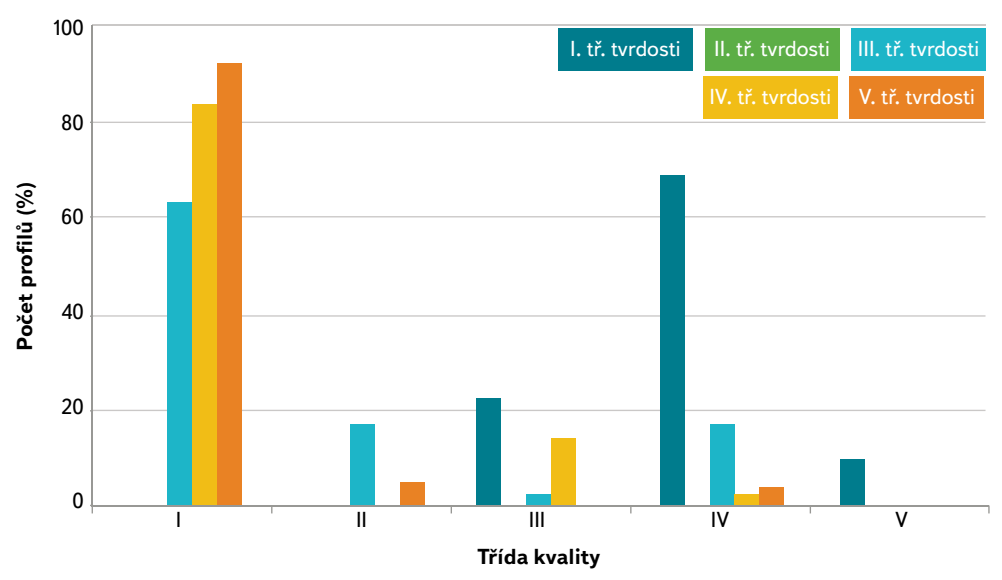

Obr. 4. Vyhodnocení klasifikace profilů sledování jakosti povrchových vod pro rozpuštěné kadmium podle nové normy ČSN 757221 z dat monitoringu za období 2011-2012 Fig. 4. Evaluation of the surface water monitoring site classification according to new ČSN 757221 from monitoring period 2011-2012

\section{BIOLOGICKÉ A MIKROBIOLOGICKÉ UKAZATELE}

V normě ČSN 757221 jsou uvedeny dva mikrobiologické ukazatele (indikátory fekálního znečištění), a to termotolerantní koliformní bakterie a enterokoky (intestinální enterokoky) a dva biologické ukazatele - saprobní index makrozoobentosu a chlorofyl-a. Mikrobiologickým ukazatelům je v tomto vydání časopisu VTEI věnován samostatný článek.

Biologické ukazatele saprobní index makrozoobentosu a chlorofyl-a byly uvedeny již v předchozí verzi normy, v rámci aktualizace normy bylo odsouhlaseno jejich zachování v seznamu ukazatelů s ohledem na jejich výhody a byla provedena revize mezních hodnot hranic tříd klasifikačních stupnic. Výhody hodnocení kvality tekoucích povrchových vod pomocí biologických ukazatelů spočívají zejména $v$ tom, že ukazatele umožňují detekovat působení vlivů komplexně a po určitou, delší dobu, čímž vyjadřují kvalitu vodního prostředí ze střednědobého hlediska. Délka této doby je závislá na použitém indikátorovém organismu - řasy poskytnou informaci krátkodobější než např. makrozoobentos.

Saprobní index makrozoobentosu vyjadřuje vztah vodních bezobratlých živočichů obývajících dnové sedimenty k ukazatelům organického znečištění a průběhu rozkladných procesů. Hodnocení kvality vody podle saprobního systému vychází z předpokladu, že v rozdílně znečištěných vodách žijí různé organismy, které se podílejí na probíhajících rozkladných procesech. Systém hodnocení je založen na toleranci jednotlivých indikačních druhů (saprobiontů) ke stupni znečištění vody. Vlastním výsledkem je tzv. saprobní index (SI), číslo, vyjadřující na stupnici saprobity $(0,5-8,5)$ stupeň znečištění biochemicky odbouratelnými organickými látkami. Saprobní index primárně indikuje organické znečištění, ale pozitivně koreluje také s intenzitou eutrofizace, zemědělským využitím říční nivy i povodí a některými prvky hydromorfologické degradace. Nevýhodou tohoto systému je, že nerozlišuje mezi přirozeným a člověkem způsobeným organickým znečištěním. Hodnota saprobního indexu tak přirozeně narůstá s řádem toku/velikostí povodí, proto je přesnější hodnotit výslednou hodnotu SI s ohledem na typ toku.

$\checkmark$ současné době je saprobní index makrozoobentosu součástí multimetrických indexů, které se použivají pro typově specifické hodnocení ekologického stavu/potenciálu vodních útvarů pro potřeby plánování v oblasti vod. Při vývoji multimetrických indexů pro hodnocení ekologického stavu podle makrozoobentosu byly provedeny u vybraných taxonů úpravy či doplnění hodnot individuálních saprobních valencí, které se využivají pro výpočet saprobního indexu. Byly také aktualizovány podklady pro výpočetní programy, které jsou na odborných pracovištích (např. státních podnicích Povodí) použivány, poslední aktualizace byla provedena $v$ roce 2016.

Pro účely normy se saprobní index počítá jako vážený aritmetický průměr individuálních saprobních indexů všech živočichů zjištěných rozborem vzorku, který byl odebrán a zpracován podle ČSN 757701 nebo ČSN 757714 a pro který jsou hodnoty tohoto individuálního indexu uvedeny $v$ informačním systému ARROW [11]. Výpočet se provádí z primárních dat, tj. data se taxonomicky neupravují (neadjustují). Při revizi došlo ke zpřísnění mezních hranic II. a III. třídy klasifikační stupnice kvality (tabulka 5).

Parametr koncentrace chlorofylu-a je snadno dostupný biologický ukazatel odrážející množství řas (fytoplanktonu) ve vodě a je základním ukazatelem biomasy řasové složky. Vysoká biomasa fytoplanktonu ovlivňuje svou fotosyntetickou činností koncentraci a diurnální změny kyslíku ve vodě a zvyšuje obsah organických látek $\left(\mathrm{BSK}_{5^{\prime}} \mathrm{CHSK}_{\mathrm{c}}\right)$. K rozvoji fytoplanktonu dochází zejména v pomalu tekoucích řekách a stojatých vodách. $V$ tekoucích vodách je biomasa fytoplanktonu, resp. koncentrace chlorofylu-a, závislá především na průtokových poměrech (inverzní vztah) a teplotě vody (pozitivní vztah) a také na množství dostupných živin. V povrchových tekoucích vodách je parametr koncentrace chlorofylu-a standardně použiván pro hodnocení ekologického stavu/ potenciálu v tocích vyšších řádů, tj. v řekách 7.-9. rádu podle Strahlera. Parametr je součástí multimetrického indexu pro hodnocení fytoplanktonu. $V$ úsecích toků nižšího řádu, které charakterizuje rychlejší proudění vody, je množství fytoplanktonu vesměs velmi nízké, a pokud se tam vyskytuje zvýšené množství fytoplanktonu, je to obvykle způsobeno existencí eutrofní vodní nádrže výše po toku.

Klasifikační stupnice byla $v$ rámci řešení projektu podrobena revizi s ohledem na akceptovanou metodu hodnocení ekologického stavu/potenciálu, ale ke změně mezních hranic tříd nedošlo. Upraven byl však požadavek minimálního počtu vzorků (6) a období odběru vzorků (ve vegetační sezoně).

\section{RADIOAKTIVITA}

Radioaktivní látky jsou v povrchových vodách jak prírodního původu, tak i jako důsledek lidské činnosti daný zejména těžbou a zpracováním uranových rud nebo vypouštěním umělých radionuklidů odpadními vodami z jaderných zařízení.

Tabulka 5. Mezni hodnoty tříd kvality - saprobní index (původní hodnoty černě, nové hodnoty červeně)

Table 5. Threshold limit values of the water quality classes - saprobic index (original values - black, new values - red)

\begin{tabular}{|c|c|c|c|c|c|c|}
\hline \multirow{2}{*}{ Ukazatel } & \multirow{2}{*}{$\begin{array}{l}\text { Měrná } \\
\text { jednotka }\end{array}$} & \multicolumn{5}{|c|}{ Třída kvality } \\
\hline & & I & II & III & IV & $\mathbf{v}$ \\
\hline $\begin{array}{l}\text { saprobní index } \\
\text { makrozoobentosu }\end{array}$ & číslo & $<1,5$ & $\begin{array}{l}<2,2 \\
<2\end{array}$ & $\begin{array}{l}<3,0 \\
<2,5\end{array}$ & $<3,5$ & $\geq 3,5$ \\
\hline
\end{tabular}


Pro klasifikaci kvality vod byly pro radioaktivní látky vybrány ukazatele celková objemová aktivita alfa, celková objemová aktivita beta, celková objemová aktivita beta po korekci na 40 K, radium 226 a tritium. Radioaktivní látkou je i uran, který je ale zařazen mezi kovy.

Celková objemová aktivita alfa na nezatižených profilech je v I. třídě kvality menší než 100 mBq/l. Celková objemová aktivita alfa větší než 100 mBq/l již indikuje jistou míru ovlivnění antropogenní činností. Úrovně nad 500 mBq/l jsou nalézány pouze v blízkosti vypouštění důlních vod nebo průsaků z odvalů z těžby uranových rud a průsaků z odkalištt. Vliv vypouštěných odpadních vod z jaderných zařízení nezvyšuje úroveň celkové objemové aktivity alfa.

$\checkmark$ ukazateli celková objemová aktivita beta jsou hodnoty neovlivněné antropogenní činností pod $300 \mathrm{mBq} / \mathrm{l}$ a patří do I. třídy kvality. Podobně jako v případě celkové objemové aktivity alfa hodnoty vyšší než 100 mBq/l indikují antropogenní ovlivnění, zejména vypouštěním důlních vod a průsaků z odkališt, jak bylo uvedeno $v$ prrípadě celkové objemové aktivity alfa. Významnou složkou celkové objemové aktivity beta je beta aktivita prírodního draslíku. Koncentrace draslíku $1 \mathrm{mg} / \mathrm{l}$ odpovídá celkové objemové aktivitě beta 0,027 Bq/l.

Na základě hodnocení vlivu vypouštěných odpadních vod z jaderných zařízení je zjištováno, že objemová aktivita beta umělých radionuklidů, konkrétně cesia 137 a stroncia 90, je zcela překrývána úrovní tohoto ukazatele na neovlivněných profilech. Vlivy jaderných zařízení spočívají v zakoncentrování odebíraných technologických vod na chladicích věžích. Významným beta zářičem je tritium, emituje však velmi měkké záření beta a jeho prítomnost není detekována při stanovení beta aktivity.

Vedle celkových objemových aktivit je limitován prrípustný obsah radia 226, jehož koncentrace na nezatížených profilech je menší než 10 mBq/l. Vyšší úrovně nejsou běžné a znamenají vliv důlních vod z těžby uranových rud. V této souvislosti je třeba ještě zmínit koncentraci uranu, která je v nezatižených tocích nižší než 5 g/l a vyšší hodnoty pak odpovídají vlivu vypouštění důlních vod, popř. průsaků z odvalů a odkališťt. Koncentrace $1 \mu \mathrm{g} / \mathrm{l}$ odpovídá objemové aktivitě alfa 0,025 Bq/I v prípadě zastoupení radioizotopů uranu v prírodním poměru.

Tritium, nejtěžši izotop vodíku, je vypouštěno běžně s odpadními vodami z jaderných elektráren. Přirozené pozadí tritia, resp. jeho reziduální úroveň po testech jaderných zbraní a část přirozeně vznikajícího prírodními procesy, interakcí kosmického záření s atmosférou, je menší než 10 Bq/l. Za jednoznačně ovlivněné profily Ize pokládat objemové aktivity vyšší než 100 Bq/l. Nejvýznamnějším zdrojem tritia $\vee$ hydrosféře byly atmosférické testy jaderných zbraní, kdy $\vee 60$. letech minulého století byla úroveň objemové aktivity tritia $\vee$ hydrosfére 100-200 Bq/l. Po ukončení testů jaderných zbraní dochází k postupnému snižování koncentrace tritia, a to jednak radioaktivním rozpadem $\mathrm{s}$ poločasem rozpadu $T_{1 / 2}=12,32 \mathrm{r}$ a postupným reděním při koloběhu vody $\vee$ prírodě. Je tak pozorován stálý pokles koncentrace tritia a jeho výskyt v současné době v povrchových vodách je kolem 1 Bq/l (pozadí). Havárie jaderného reaktoru v Černobylu a ve Fukušimě nevedla ke zvýšení koncentrace tritia v České republice.

Stanovení koncentrace radioaktivních látek ve vodě se běžně provádí v rozpuštěných a nerozpuštěných látkách celkem. Celkové objemové aktivity alfa a beta Ize stanovit samostatně $v$ rozpuštěných a nerozpuštěných látkách. Součet těchto celkových objemových aktivit znamená hodnotu celkových objemových aktivit alfa a beta ve veškerých látkách. To platí i o součtu koncentrací radia 226 nebo uranu.

Souhrnně lze konstatovat, že dochází k poklesu koncentrací radioaktivních látek v povrchových vodách, tedy ke zlepšování kvality vod v těchto ukazatelích, s výjimkou koncentrace tritia, které je však na velice nízkých pozad’ových hodnotách.

\section{ZÁVĚR}

Novelizovaná norma ČSN 757221 lépe koreluje se současnými požadavky ochrany povrchových vod prí zachování shodného principu klasifikace. Pro více ukazatelů, než se původně predpokládalo, jsou zachovány mezní hodnoty tříd kvality, čímž je zachována alespoň částečná kontinuita vyhodnocování kvality z předchozích let. Došlo k rozšíření spektra ukazatelů znečištění ze 46 na 65, resp. 70, pokud zahrneme i rozpuštěné formy vybraných kovů. Norma představuje nástroj možného každoročního hodnocení kvality vody a srovnání vývoje kvality v delším časovém horizontu v zájmových profilech pro sledování jakosti povrchových vod. Tím, že využívá charakteristickou hodnotu $C_{90^{\prime}}$ popř. maximum, může být také doplňujícím nástrojem k hodnocení stavu vod podle Rámcové směrnice pro vodní politiku Společenství 2000/60/ES, využívající většinou roční průměrnou koncentraci nebo medián. Nově je umožněno orientační posouzení kvality vody při četnosti naměřených hodnot menší, než je stanoveno v odstavcích 4.5 a 4.6 normy. To umožňuje využití normy širší skupinou uživatelů z řad fyzických i právnických osob a samosprávy v provedení rychlého orientačního zhodnocení znečištění povrchové vody v libovolném zvoleném místě říční sítě.

\section{Poznámky}

1. Nařízení vlády č. 171/1992 Sb., nařízení vlády č. 82/1999 Sb., nařízení vlády č. 61/2003 Sb., ve znění nařízení vlády č. 229/2007 Sb. a č. 23/2011 Sb., a nařízení vlády č. 401/2015 Sb.

\section{Poděkování}

Článek vznikl za podpory projektu Kvalita a hodnocenípovrchových vod - TD 03000215 $\checkmark$ rámci Programu na podporu aplikovaného společenskovědního výzkumu a experimentálního vývoje OMEGA.

\section{Literatura}

[1] ČSN 757221 Kvalita vod - Klasifikace kvality povrchových vod. Úřad pro technickou normalizaci, metrologii a státní zkušebnictví, 2017.

[2] ČSN 757221 Jakost vod - Klasifikace jakosti povrchových vod. Český normalizační institut, 1998.

[3] Nařízení vlády č. 401/2015 Sb., o ukazatelích a hodnotách přípustného znečištění povrchových vod a odpadních vod, náležitostech povolení k vypouštění odpadních vod do vod povrchových a do kanalizací a o citlivých oblastech.

[4] Nařízení vlády č. 171/1992 Sb., kterým se stanoví ukazatele př́pustného stupně znečištění vod.

[5] PITTER, P. Hydrochemie 4. aktualizované vydání. Praha: VŠCHT, 2009. ISBN 978-80-7080-9.

[6] FIEDLER, D., GRAEBER, D., BADRIAN, M., and KÖHLER, J. Growth response of four freshwater algal species to dissolved organic nitrogen of different concentration and complexity. Freshwater Biology, 2015, 60, p. 1613-1621

[7] GRIMVALL, A., ASPLUND, G., BORÉN, H., and JONSSON, S. Origin of Adsorbable Organic Halogens (AOX) in Aquatic Environment. In: Angeletti, G., et. al. Organic Micropollutants in the Aquatic Environment. Springer Science + Business Media Dordrecht, 1991.

[8] RUBIN, B.S. Bisphenol A: an endocrine disruptor with widespread exposure and multiple effects. J. Steroid Biochem. Mol. Biol., 2011, vol. 127, No. 1-2, p. 27-34.

[9] European Chemicals Agency. Seznam látek vzbuzujících mimořádné obavy podléhajících povolení. Dostupné z: https://echa.europa.eu/cs/candidate-list-table?

[10] SOLOMON, F. Impacts of Metals on Aquatic Ecosystems and Human Health. MINING.com, April 2008. [11] Informační systém ARROW. Dostupné z: http://hydro.chmi.cz/isarrow/ 
